\title{
"What a Man Does Not Know Is Greater than He": Analyzing Noos, Thymos and Akrasia in Achebe's Arrow of God
}

\author{
Samrand Avestan ${ }^{1} \&$ Owen G. Mordaunt ${ }^{2}$ \\ ${ }^{1}$ Faculty of Literature and Humanities, Kharazmi University, Tehran, Iran \\ ${ }^{2}$ Department of English, University of Nebraska at Omaha, Omaha, Nebraska, USA \\ Correspondence: Owen G. Mordaunt, Department of English, University of Nebraska at Omaha, Omaha, \\ Nebraska, USA.
}

Received: October 5, 2021

Accepted: November 14, 2021

Online Published: November 22, 2021

doi:10.5539/ells.v12n1p1

URL: https://doi.org/10.5539/ells.v12n1p1

\begin{abstract}
This paper is an exposition of how Chinua Achebe's Arrow of God (1964) is engaged with philosophical concepts of thymos, noos, eros, and akrasia. The focus of this study is principally on Ezeulu's thymos. To achieve this end, Francis Fukuyama's notion of thymos or "desire for recognition" has been considered to provide a more tangible description of the term. This study explores that when a person's body formation is mostly dominated by thymos, which has run out of control, the result is akrasia. Subsequently, it will be discussed that Ezeulu's akrasia or "weakness in will" is the result of his ambivalent quest for self-worth. This article also seeks to examine the ways in which Ezeulu, the Chief Priest of Ulu, struggles to maintain his dignity to remain Umuaro's cynosure. Ezeulu's old age, his poor eyesight, his conflicts with his people, his insistence on revenge, and his desire for higher values provide some of the major sources of akrasia. By applying these aforementioned philosophical concepts to this novel, it is hoped that this article will contribute to a new conceptualization in terms of psychic disposition in Achebe's Arrow of God.
\end{abstract}

Keywords: noos, thymos, eros, akrasia, the chief priest of Ulu, Chinua Achebe

\section{Introduction}

With an intricate and periphrastic narrative, Chinua Achebe's third novel Arrow of God (Note 1) embarks on issues dealing with an important milestone in Umuaro (Note 2) in 1921. The novel pursues the story of Ezeulu, the Chief Priest of Ulu (a deity), whose one half "was man and the other half mmo - the half that was painted over with white chalk at important religious moments. And half of the things he ever did were done by this spirit side" (Achebe, 1974, p. 192). His mixed involvement with colonial administrators and Christian missionaries, ultimately, led to local people's distrust of Ulu, a hallowed symbol of Igbo culture. Being set in the period between pacification and independence in Umuaro, the novel depicts slow death of Igbo culture during the colonial era. According to Suzanne Scafe (2002), the novel describes "a culture on the brink of change [wherein] ... the effects of colonialism have already reached the villages" (p. 126). Ostensibly, the thematic understanding of Arrow of God has become a fulcrum for debate. Chima Osakwe (2010) explores how the concept of "literacy" serves as "a determinant of social status" (p. 130). In other words, he asserts that lack of written communication in Umuaro diminishes the villagers" "prestige" (Note 3) and "worth" in the eyes of the white colonists (p. 131). Maureen Warner Lewis (1974) analyzes the social and personal conflicts existing in Umuaro; she also analyzes Ezeulu's strength, faults and doubts, claiming that they stem from his "stubborn pride" (p. 75). Suzanne Scafe (2002) examines the presence of duality and difference in Achebe's two novels, which particularly prevailed in his proverbs as "necessary conditions of existence" (p. 119). Blaise N. Machila (1981) also examines various "conflicts" (p. 119) which developed around Ezeulu. Machila assumes that although Ezeulu possess a "superior intelligence, ... it is precisely in this strength of broad comprehension that Ezeulu's total weakness lies" (p. 133). Additionally, M. J. Melamu (1971) in "The Quest for Power in Achebe's Arrow of God" alleges that Ezeulu's awareness of his deficiencies, like his "failing vision" (p. 225) and "receding strength" (p. 226), urge him to have an "insatiable greed for power," a type of fallacious desire that he himself is the first victim of (p. 240). Even though, these studies illuminated Ezeulu's strength, conflict and weakness in their own particular ways, in interpreting Arrow of God, we would like to expand Ezeulu's character by touching on Ancient Greek emotions like thymos (Note 4) which we prove leads to akrasia. Although principally this study explores thymos in relation 
with akrasia, other terms such as noos (Note 5) and eros (Note 6) are discussed as well.

This paper touches on Francis Fukuyama's notion of the term foregrounded in his book titled The End of History and the Last Man (1992). Historically, thymos stems from a Greek expression roughly signifying "spiritedness" (Fukuyama, 2006, p. 1163). The term is originally applied by Homer (800-700 BC) in The Iliad harboring emotional feelings and passions (Koziak, 1999, p. 1069). Furthermore, it is considered as "an organ of emotion, intellect, and will" in Homer (M. Darcus, 1977, p. 182). The concept of thymos is proposed subtly by Plato in The Republic (380 BC). It is based on Socrates' dialogue, wherein Plato concludes that there are basically three parts to the soul: "a rational principle," "an irrational or appetitive principle" and, finally, "passion or spirit" that if not "corrupted by bad education is the natural auxiliary of reason (Jowett, 1998, pp. 124-125). More simply put, based on Fukuyama's interpretation, it is argued that " $[\mathrm{m}] \mathrm{uch}$ of human behavior can be explained as a combination of the first two parts, desire and reason; desire induces men to seek things outside themselves, while reason or calculation shows them the best way to get them" (2006, p. 16). In essence, being derived half from noos (reason) and half from eros (desire), thymos plays a crucial role in determining an individual's behavior. Through foregrounding, Fukuyama portrays thymos politically and psychologically as:

$[\ldots]$ the desire for recognition [...] human beings seek recognition of their own worth, or of the people, things, or principles that they invest with worth. The propensity to invest the self with a certain value, and to demand recognition for that value, is what in today's popular language we would call 'self-esteem' (Note 7). The propensity to feel self-esteem arises out of the part of the soul called thymos. It is like an innate human sense of justice (p. 17).

Fukuyama broadens the concept of thymos and introduces Megalothymia or "the desire to be recognized as superior" (p. 190) and isothymia which refers to "the desire to be recognized as the equal of other people" (p. 182). Although Fukuyama mostly focuses on the constructing feature of thymos, with remarks on Susan M. Purviance (2008), we would like also to add that thymos "detonates" and "lead to actions that destroy civic life" (p. 4). Conceivably, the tension between groups or individuals arises when people's equal justice and rights are ignored by some other domineering group.

Socrates in Phaedrus (Note 8), allegorically portrays the first part of soul (noos) as a "charioteer" seeking "wisdom, or truth" with his team of two winged horses: "the well-behaved white horse [thymos]" signifies "the love of honor and propriety" and "the violent black horse [eros $]$... represents the simple need to have one's way" (Ferrari, 1992, p. 264). Unlike thymos that is revealed and easily distinguished, according to Shirley Darcus Sullivan and Richard D. Sullivan (1990), noos "may not be easily grasped by others" (p. 183). Noos is "the reasoning or calculating part" (Fukuyama, 2006, p. 164) of soul that leads individual to have a clear vision of the past, present and future situation.

Aligned with Fukuyama's study, thymos is the source of "noble virtues" (Note 9) (p. 117) which all scientists call "values" (p. 213) and is considered as a positive and determinant factor for establishing a dynamic and just society. Nonetheless, thymos has also a negative state or "dark side" (p. 181) which may drive the person towards a "form of passionate and stubborn pride" (p. 185). Accordingly, in this study we refer to the projection of self-assertive values and selfishness as akrasia as illuminated in Ezeulu's body formation. Taking Fukuyama's study into account, it is stated that when an individual acts based on his thymos and not noos, the result is akrasia.

Akrasia is also a Greek term that has been translated as "lack of self-control" (Destrée, 2007, p. 139), "weakness of will" (Holton, 1999, p. 241), "incontinence" (McConnell, 1975, p. 635), "moral weakness" (Henry, 2002, p. 255), and "weakness of character" (Rorty, 1970, p. 50). An akratic person experiences passions that are at variance with his rational principle. In other words, he makes decisions mostly based on his feelings rather than his reason. Amelie Rorty's (1970) infers that according to Aristotle, "the man suffering from akrasia is overcome by passion so that he cannot use, but only mouths, his better judgment" (p. 50). He adds that "The man who suffers from akrasia only appears to know, or mistakenly thinks that he knows, but obviously cannot actually fully realize or understand what is to his interest" (p. 50). Influenced by Plato's tripartite division of soul, Aristotle argues that "akrasia implies a conflict between two parts of the soul, a rational part and an irrational one, the weakness of the rational part being unable to dominate the irrational one" (Gourinat, 2007, p. 217).

In this paper, the aim is to show that Ezeulu's calculations are not correct and his thymotic passions are the major factors driving him towards akrasia. Although thymos, if well-developed, can work as a propeller and force for action to defend dignity. This study proves that thymos is leading Ezeulu to make incorrect decisions and foretelling resulting in akrasia or weakness in making judgment. 


\section{Discussion}

Craving for recognition, Ezeulu desires to be seen equal to Ulu, a deity who is allegedly a source of spiritual power for the villagers. Likewise, the colonial administrators deployed by the British colonial administration make effort to embody its own ideology and domination in Umuaro, in the course of time. In consonance with Fukuyama's interpretation, it has been illuminated that Ezeulu' and the white colonizers' share a similar desire for recognition. What they are pursuing can be deducted from Fukuyama's words as their "desire for religious mastery - that is, the recognition of one's own gods and idols by other peoples" (2006, p. 259). In addition to this, Emmanuel Obiechina (1975) points out that "collective security" (p. 235) is viewed as prominent longings for Ezeulu and people of his ilk. To achieve this end, they have been worshiping different deities, like Idemili, Ogwugwu and Eru and Udo (Note 10), who could both safeguard them, and also move in parallels with their desires. The weakest among them, Ulu, has been chosen and authorized as a "protector" (Achebe, 1974, p. 27) to balance the power among gods. It is alleged that the priesthood of Ulu is offered to the weakest village of Umuaro to keep the balance and ensure that none of the villages overpower the others.

Clearly, Ezeulu's ambivalent behavior and action stem from his desire to play a crucial role in Umuaro and to impose his will upon the villagers. Likewise, Anthonia C. Kalu (1994) argues that "the nature of Ulu makes it necessary for him to be concerned with Umuaro's safety and to play an important philosophical role in the socio-political welfare of the people" (p. 56). Ezeulu is well aware that "the priests of Idemili and Ogwugwu and Eru and Udo" (Achebe, 1974, p. 40) are not satisfied with their marginalized role. He knows that sooner or later one of these deities will challenge Ulu, and, in particular, he himself, as the Chief Priest. Cautiously, he is evaluating "the immensity of his power over the year and the crops and, therefore, over the people" and he is doubtful whether his influence is "real" (p. 3). Albeit Ezeulu is alleged to possess high moral standards and superiority in pursuit of higher ranks, weak spots are vivid in his personality and behaviors. The novel begins by referring to Ezeulu's poor eyesight and his weakness in distinguishing the appearance of the new moon. Yet, owning to his megalomaniac stubbornness:

Ezeulu did not like to think that his sight was no longer as good as it used to be and that someday he would have to rely on someone else's eyes as his grandfather had done when his sight failed. Of course, he had lived to such a great age that his blindness became like an ornament on him. If Ezeulu lived to be so old he too would accept such a loss. But for the present he was as good as any young man, or better because young men were no longer what they used to be. There was one game Ezeulu never tired of playing on them. Whenever they shook hands with him, he tensed his arm and put all his power into the grip, and being unprepared for it they winced and recoiled with pain (pp. 1-2).

Seemingly, his poor eyesight foreshadows the loss of his influence among indigenous people, as the chief priest of Ulu must have astute eyes to have the priority of seeing the new moon before anyone else does. As long as Ezeulu's eyesight gets poorer and his vision from reality gets dimmer, he has to take refuge to dreams and prophets. Similarly, M. J. Melanu (1971) states:

Ezeulu seems to believe that his judgements only are the right ones, and this leads him into a serious error of judgement when he seeks to elevate himself to a level of equality with Ulu so that in the end he loses sight of the dichotomy that ought to exist between god and man (p. 235).

Apparently, in Ezeulu's case, thymos or desire for recognition and honor has the upper hand; that is to say, that his noos will be subjugated to his thymotic desire for wining admiration. Relying on Shirley Darcus Sullivan's interpretation of Mimnermus's poem, the Greek elegiac poet (630-600 BC), the effect of old age may harm noos (inner vision) and eyesight (outward vision). That means as people grow older, both their noos and eyesight hurts. Similarly, she contends that "noos may be the source of inner vision just as eyes are the source of outer vision. Old age damages man's ability to perceive situations and their significance, just as his external sight begins to dim" (2010, p. 9) (Note 11). A person who loses his vision becomes "worthless," a foible which is not easily accepted by Ezeulu who passionately tends to keep his "self-worth" (Note 12) (Fukuyama, 2006, p. 19). Ezeulu's self-esteem is greatly affected by a genuine struggle between him, "his own rival tribe, the British administrators, and Christian missionaries" (Mordaunt, 1989, p. 154). Further, the point needs stressing that in an honor-seeking person like Ezeulu, the appetitive drive (eros) does not play a crucial role in his personality. He is not following anything that is mostly organized around his animal-like desires, which are considered to be morally base. Also, Ezeulu's favorite son, Obika, is a good example of a thymotic man or "the man of anger" (Fukuyama, 2006, p. 80). He possesses a type of "manly voice" (Achebe, 1974, p. 7) and he is "one of the handsomest young men in Umuaro and all the surrounding districts" attributing him to have been lived with the "riverain folk whom the Igbo called Olu" (p. 10). Nevertheless, it has been said that that "two things spoilt Obika. He drank palm wine to 
excess, and he was given to sudden and fiery anger. And being as strong as rock, he was always inflicting injury on others" (p. 10). On this account, it can be deduced that a fiery man is not very likable in Umuaro. While, in practice, Ezeulu praises his son's courage and fearlessness, sometimes he advises him to be "coward" (p. 11). Put in another language, he tells his son to use his noos or inner vision. He cites that: "[w]e often stand in the compound of a coward to point at the ruins where a brave man used to live. The man who has never submitted to anything will soon submit to the burial mat" (p. 11). He foretells that a wise man must control his thymos and let his noos rule him. Having said that, in reality, "Ezeulu would rather have a sharp boy who broke utensils in his haste than a slow and careful snail" (p. 11). Ezeulu knows that if the domination of thymos outweighs noos, it may endanger an individual's life; at heart, he praises the thymotic man.

For Socrates, based on Jonathan Lear's notion, there is merely "one stable, harmonious and happy personality-formation" which is possessed by a "just" individual. In such an individual reason has dominance, "it lets spirit feed on what is truly honorable; and allows the appetites to be gratified only in healthy ways. All other personality-formations are unstable and disharmonious to some degree: one should expect division and strife among the parts" (2006, p. 458). Considering that, Ezeulu is an ideal candidate for a thymotic man whose personality formation is controlled by his thymos-not noos. Like Thrasymachus, Ezeulu is a "spirited, honor-loving personality" whose soul is "[...] organized around thymos." In other words, it is thymos that influences his notion of "justice" and urges him to see himself as a person who owns certain rights and dignity that surely must be defended. Such thymotic person creates criteria based on which justice is defined. Hence, in such a personality-organization, noos is subjugated to thymos, and is "unstable." It can be added that, although, like Thrasymachus, Ezeulu's reason is "crippled and distorted by thumos, there is some aspect of it which aspires to truth" (p. 458). There are striking similarities in the desires of Ezeulu and thymotic man but then there are still areas in which Ezeulu might be said to have bent towards using his mind and better judgment.

By the same token, when a murderous war between Umuaro and Okperi breaks out on a disputed plot of land, the thymos of both sides was instigated. Thymos pertains to defending one's honor, dignity, and sense of justice, which the people of both sides deem righteous. Drawing on contemporary theorists, Barbara Koziak foregrounds that thymos is "expressed as anger against violations of one's honor" $(1999$, p. 1081). For this reason, on the day the war broke out "Umuaro killed two men of Okperi ... the fighting grew fierce. Umuaro killed four men and Okperi replied with three" (Achebe, 1974, p. 28). The war proceeded to imperil the security of all sides, that is to thoroughly reave the insouciant security which villagers had ideated long ago. In actuality, the war is at loggerheads with Ulu's desire, and Ezeulu realizes that his deity is not influential enough to extinguish the war. Afterwards, "the white man, Wintabota, brought soldiers to Umuaro and stopped it... He gathered all the guns in Umuaro and asked the soldiers to break them in the face of all ...." (p. 28). Unexpectedly, while the white man looks for the verdicts to discern the causes of the war, Ezeulu witnesses that Okperi is the real owner of the land. In response, Winterbottom "called Ezeulu the only witness of truth" (p. 3). Although some parts of Ezeulu's soul seeks for truth, and his noos struggles to rule over his thymotic passions in the long term, his thymos overpowers other parts of soul, like noos and eros. The domination of his thymotic passions drives Ezeulu towards akrasia. More pointedly, his akrasia is increased when he is flattered by the white man who had called him the most honest person. Warner Lewis put it pointedly: "he sees the white man as his "ally" against Umuaro and, in a possible interpretation, transfers his own assessment onto a spiritual plane, thus thinking in terms of 'alliance' between Ulu and the Christian religion" (p. 77). What Ezeulu preaches contradicts what in reality he pursues. On the one hand, he teases that "the man who brings ant-infested faggots into his hut should not grumble when lizards begin to pay him a visit" (p. 132). However, ironically, he himself, whether consciously or unintentionally, is a major catalyst in establishing the dominance of the white men. Apparently, Ezeulu's decision to tell the truth can be viewed as a gesture of goodwill to end the war for the benefit of the Okperi people whom Ezeulu believes to be the first and true owner of the land; nonetheless, his decision, similar to Edward Said's comment, provides cogent reasons for the white foreigners to establish "the world of imperialist polemic in which, the native is naturally a delinquent, the white man a stern but moral parent and judge" (1994, p. 148). Subsequently, the white man "sat in judgment over Umuaro and Okperi and gave the disputed land to Okperi" (Achebe, 1974, p. 29). As such, according to Alastair Pennycook, it was a short step to see "colonized people as children and the colonizers as adults" (1998, p. 60).

Confident enough to show power to the natives, the colonizer struggles to foreground his superiority and megalothymia via utilizing martial equipment. Likewise, he boasts to possess a type of heavenly capabilities with mechanical apparatus in his service, since it is considered by the villagers that "the white man has a gun, a matchet, a bow and carries fire in his mouth" and "does not fight with one weapon alone" (Achebe, 1974, p. 85). As a result, indigenous people, both from Okperi and Umuaro, gradually acquiesced to the coercive judgment, as 
the judge (the colonizer) has sufficient power to fixate security. Considering their presence and objective, with reference to Fukuyama's remark on the colonizers" "quest for glory," it can be deduced that "the logic of recognition ultimately led to the desire to be universally recognized, that is, to imperialism" (2006, p. 182). Conspicuously, the similarities between the white man and Ezeulu are brought to light as both of them are enthusiastically penchant for ruling and raising their profiles. Ostensibly, however, Ezeulu's akrasia results in not seeing the true intention of the white colonists. Accordingly, his desire for thymos and presenting his worth to the white man opens a wide rift between him as the quintessential symbol of Igbo culture and his own people. Although Ezeulu does not face death, thematically he shares common features with tragic heroes (Note 13). Indeed, out of ignorance, he makes a chain of mistakes and errors that are "neither pitiful nor terrible." In Poetics, Aristotle mentions that tragic character "... is not eminently good and just, yet whose misfortune is brought about not by vice or depravity, but by some error or frailty" (Butcher, 1907, p. 45). Likewise, Ezeulu's megalomania and stubbornness are regarded as major flaws compelling him to precipitate his abandoning. In case these changes would threaten his position and status, Ezeulu is very skeptical of the changes happening in the surroundings. His thymos propels him to preserve his status as the Chief Priest of Ulu at any cost and not losing it after eighteen years. Egotistically, being deposed from his status is "painful" and being "away" from Ulu he feels "a little like a child whose stern parent had gone on a journey" (Achebe, 1974, p. 160). By losing Ulu, he loses his source of power and dignity. To keep his authority, based on David Carroll's comments, "Ezeulu is constantly tempted to mingle his own wishes with those of the god and then assert his authority over the six villages by means of Ulu's oracular power" (1990, p. 89).

Pursuing his life through reading the book, conspicuously, Ezeulu reveals extreme duality in his bearings and dispositions. Based on Bill Ashcroft et al., this complex mix of "attraction and repulsion" between Ezeulu and the colonizers is ambivalent "because the colonized subject is never simply and completely opposed to the colonizer" (2007, p. 10). Ezeulu's akrasia has its roots in his ambivalent tendency towards the white colonizers. When the white colonizers enter Umuaro, it is anticipated that as the Chief Priest of Ulu, Ezeulu acts as a fierce counterforce to a foreign dominance. On the contrary, his lack of noos, tinged with hubris and some whims of ignorance, leads to akrasia. His moral weakness in judgment paves the way for the colonizers to fix their position and diffuse their ideology. An example of an akratic belief stems from this saying that "the world is like a Mask dancing. If you want to see it well, you do not stand in the same place" (Achebe, 1974, p. 46). Likewise, in this matter, Machila (1981) argues:

But it is precisely in this strength of broad comprehension that Ezeulu's total weakness lies. In his belief that the mask of the world can actually be seen in its entirety, he forgets that some phases of reality can never be known because of the limited capabilities of man. The ignorance of this fact, as well as the consequence of that ignorance, is inevitable in one form or another (p. 133).

In addition to his distracted inner equilibrium, Ezeulu believes that he is the only one who knows the truth. He is unaware that he may not be on the right side, so that he neglects complains and criticisms. Moreover, Ogbuefi Akuebue, Ezeulu's intimate friend, had warned him before that:

"it is the pride of Umuaro [...] that we never see one party as right and the other wrong. [...] in all great compounds there must be people of all minds - some good, some bad, some fearless and some cowardly; those who bring in wealth and those who scatter it, those who give good advice and those who only speak the words of palm wine." (Achebe, 1974, p. 100).

In Umuaro, the thymos of each group must be respected. Thymos is a desire for recognition evident in each person, more or less an emotion that Ezeulu overlook. Thymos "is like an innate human sense of justice. People believe that they have a certain worth, and when other people treat them as though they are worth less than that, they experience the emotion of anger" (Fukuyama, 2006, p. 17). Ezeulu is furious with the backbiting and gossips of his neighbors and fellow folks; he believes that Nwaka, the priest of Idemili, is responsible for all these verbal attacks. His frequent vision and phobia center on Umuaro villagers abandoning Ulu. Abandoning him as the Chief Priest of Ulu spurs him to think self-assertively of taking revenge on his people. And "anyone who dared to say "no" to him was an enemy. He forgot the saying of the elders: that if a man sought for a companion who acted entirely like himself, he would live in solitude" (Achebe, 1974, p. 92). Disregarding what is basically reasonable, he considers the other people's opposition as blasphemy and disrespect in a way that "every time he prayed for Umuaro bitterness rose into his mouth, a great smouldering anger for the division which had come to the six villages and which his enemies tried to lay on his head" (p. 6). Aristotle in The Politics holds that "to be ill-treated makes men follow their passions rather than their reason ...." (Sinclair \& Saunders, 1981, p. 341). In parallel, to defend his "recognition and dignity" (Fukuyama, 2006, p. 201), Ezeulu follows his thymos. In line with Fukuyama's study, Ezeulu is not following worldly comfort but "a desire for a desire", in other words, "a 
desire that that person who evaluated us too low should change his opinion and recognize us according to our own estimate of our worth" (p. 165). Nonetheless, Ezeulu's decision to retaliate and teach a lesson to his people forces him to turn to another akrasia.

In effect Ezeulu's second akrasia results in his attempt to realize the white colonizers' source of power. Akrastically Ezeulu believes that the white man's source of power derives largely from his ability to write with the left hand:

I saw a young white man who was able to write his book with the left hand; he could shout in my face; he could do what he liked. Why? Because he could write with his left hand. [...] I want you to learn and master this man's knowledge so much that if you are suddenly woken up from sleep and asked what it is you will reply. You must learn it until you can write it with your left hand (Achebe, 1974, p. 189).

Ezeulu strives to maintain balance between the traditional customs and the new phenomena. Discernibly, as the first man in Umuaro, he consigns one of his own sons, Oduche, to work as a servant for the colonizers. From the British standpoint, this is partly an execution of colonial power. Regarding this matter, Carroll reveals that "Oduche's presence among the missionaries is prompted by his father's need for power ...." (1990, p. 105). Notwithstanding, Ezeulu conceals his real intention by citing that: "I want one of my sons to join these people [outsiders] and be my eye there" (Achebe, 1974, p. 45). He hides his noos or inner vision from people. He tries to keep up with the changes, but the irony is that his noos is not improving in line with pace of the society at large. His thymos tantalizes him to have more power and influence; but even so his noos is unable to predict the future of many events especially of his son. Sometimes the thymos obscures the noos. In other words, emotional feelings are in contrast with intellectual senses.

Ezeulu's conflict is that the white man's religion may spur people to break Igbo's taboos and violate traditional customs. Even he is warning that the strangers' religion is like "a leper. Allow him a handshake and he wants to embrace" (p. 43). However, having discovered that his son has proselytized, neither did Ezeulu proscribe him nor bring him back home. In a downbeat assessment, conservatively, he ponders that if the prophesies of the many oracles are construed and the white men dominate the land in his control "in such a case it would be wise to have a man of your family in his band" (p. 42). His obscure dispositions towards the exotic religion and culture are mixed with a compromising of hatred and inclination. The relationship between Ezeulu and white man can be described in Homi Bhabha's wording as "ambivalent" because it appears that "the colonized subject is never simply and completely opposed to the colonizer" (Ashcroft et al., 2007, p. 10). Ambiguities in Ezeulu's behaviors can be compared to his inclination towards the white colonizers and his symbolic abandonment of the ancestors' customs. To them, a Chief Priest like him should not have sent his son to the service of the white men whom he feigns to oppose. Hence, by exposing Oduche - who is young and naïve - to the white man's ideology, and more particularly his language, Ezeulu acts based on his thymos rather than his noos. Ignoring villagers' impugning, he consciously ponders that there must be benefits in taking on the white men's ways, more specifically, their wisdom. Thus, in a prospective decision, he prompts his son to seize some of white man's prominent features:

At first, he had thought that since the white man had come with great power and conquest it was necessary that some people should learn the ways of his deity. That was why he had agreed to send his son, Oduche, to learn the new ritual. He also wanted him to learn the white man's wisdom, for Ezeulu knew from what he saw of Wintabota and the stories he heard about his people that the white man was very wise (Achebe, 1974, p. 42)

However, Ezeulu cannot predict that his son will act against him and his culture. With the aim of expanding the colonizers' religion, Mr. Goodcountry admonishes the convertors against Igbo customs and refers to them as "bad customs." He asserts that:

If we are Christians, we must be ready to die for the faith ... you must be ready to kill the python as the people of the rivers killed the iguana. You address the python as Father. It is nothing but a snake, the snake that deceived our first mother, Eve. If you are afraid to kill it do not count yourself a Christian (p. 47).

As a sign of refusal to the ancestral culture, Oduche imprisons the royal python, belonging to Idemili, a blasphemy that causes a disturbance among villagers. Not only does Ezeulu turn a blind eye to Oduche's proselytizing, but, also, he goes further to ironically censure those who have suffered from the white men's grievance. Put it in another illustration, when Obika, his favorite son, is whipped by one of the colonizers' agents (Mr. Wright), Ezeulu admonished him rather than lends an ear impartially to his plaint. Having heard Obika's complaints, he asserts that from what he knows Obika "is likely to have struck the first blow, especially as he was drunk when he left home" (p. 88). Thereby, Ezeulu's penchant for power drives him to scapegoat his closest 
ring of devotees. Thus, as Melamu affirms, "he scatters the people apart-not only the members of his family, but also the society at large" (1971, p. 234). Although Ezeulu is a thymotic man, according to D. Ibe Nwoga there is no doubt about his "greatness, his uprightness, his fearlessness, and above all his steadfast adherence to the dictates of religious conscience," he does not have voice of all with himself and in many ways in Umuaro, Ezeulu is not "a likable man" (1981, p. 27). Precariously, his internal need for power and supremacy urged him to gamble on truth by denying it, which in fact alienated villagers with Igbo culture and also Ulu, whose domain of influence was going to shrink away gradually. Overwhelmed by thymos, he neglects the slow dominance of the white man's presence. Too close are the church tolls, he sometimes gets distracted while preparing for the religious rites:

The place where the Christians built their place of worship was not far from Ezeulu's compound. As he sat in his obi thinking of the Festival of the Pumpkin Leaves, he heard their bell: GOME, GOME, GOME, GOME, GOME. His mind turned from the festival to the new religion. He was not sure what to make of it (Achebe, 1974, p. 42).

He is unaware that his vulnerable Ulu is losing his influence mostly in light of his akrasia and the colonists' dominance. Ezeulu does not know that his desire for recognition blinds his inner vision or noos to the truth that his people are not his true enemy.

By denying the truth of observing the new moon, Ezeulu's final akrasia happens which has dire consequences. His gamble to take revenge on his people coincides with colonizers' intention to choose an "indirect rule based on native institutions" (Achebe, 1974, p. 56). No candidate can be more qualified than a spiritual chief like Ezeulu in a traditional and patriarchal community. In fact, "[t]his was what the British administration was doing among the Ibos, making a dozen mushroom kings grow where there was none before" (p. 58). The imperial colonizers in pursuit of dominance and recognition strive to justify "moral ambiguities of thymos" (Fukuyama, 2006, p. 183). Therefore, to achieve this end, they are "trying to make use of its positive aspects and seeking a way to neutralize its dark side" (p. 183). Likewise, by posing Ezeulu as the indirect rule, virtually, colonizers' problem with just political order is solved. They try to maintain a balance between their own thymos and the village's desire for peace and security. Thus, Ezeulu is a prominent candidate whose words get attention, and he is alleged to possess noos. Still and all, Ezeulu's personality is organized mostly around thymos. He more and more thinks of maintaining his own "worth and dignity" (p. 193) rather than the villagers' true needs. He tries to impress his clan and devotees with the power of witchcraft and thinks that the white colonists respect him and appreciate his thymos. Therefore, when Captain Winterbottom deploys a messenger to present Ezeulu to him, Ezeulu refuses to go with him. He justifies his denial by saying that the priest of Ulu doesn't depart from his obi (compound) and urges that if any visit is required, it must be done in his place. His meglothymic passions are with him even when two men are coming to arrest him. He admonishes them that they have indeed "walked into the mouth of a leopard" (Achebe, 1974, p. 158).

Based on Fukuyama's comment, Ezeulu believes that what he deserves most is "respect" since he possesses specific "value or dignity" (2006, p. 152). Ironically, contrary to what he said, Ezeulu himself sets out for Okperi, to the location of Winterbottom. Without referring to his noos and his ability to distinguish the situation, unwittingly, Ezeulu refuses the offered position by the white man. According to Machila (1981) "Ezeulu's refusal to come running for a chieftainship from Winterbottom precipitates the crisis that culminates in Umuaro people's desertion of their god Ulu for the god of the Christians" (p. 126). He believes that his refusal to the given position elevates his "prestige and dignity" (Fukuyama, 2006, p. 96). However, in practice, the white man imprisons him in Okperi which in its turn this incident causes a delay in declaring the new moon festival.

In confinement, idiosyncratically, Ezeulu does not review his noos, rather his thymos rules in him which leads him to akrasia. He believes that "his quarrel with the white man was insignificant beside the matter he must settle with his own people" (Achebe, 1974, p. 160). Ezeulu does not understand that his true enemy is the presence and domination of the white colonists entrenching their religion. Akrastically, he uses his detention as a propitious pretext to "to hit Umuaro at its most vulnerable point - the Feast of the New Yam" (p. 202). Indeed, the given festival is considered as the last remaining linkage between Ulu and the villagers; since Ulu, a deity of dawn and also fertility must send his blessings via his Chief Priest to his worshipers. Discovering this bond, Ezeulu sees this skein of connection as the villagers' Achilles heel to be used. Contrary to all expectations, his refusal to make an announcement after being released from incarceration causes Umuaro's crop to rot away in the ground as "his greatest pleasure came from the thought of his revenge" (p. 160). As a result of Ezeulu's obstinacy, a severe famine sweeps through Umuaro, leading to impoverishment and even the death of his own favorite son, Obika. Meanwhile, John Jaja Goodcountry, a religious missionary, considers this calamity in Umuaro as "an opportunity for fruitful intervention" (p. 215). In contradiction to Ezeulu whose soul is mostly organized by thymotic passion, the 
colonist uses his noos and judgment to fix his position and popularity. "He had planned his church's harvest service for the second Sunday in November the proceeds from which would go into the fund for building a place of worship more worthy of God and of Umuaro. His plan was quite simple" (p. 215). Although, the colonist ethereally attempts to save Igbo people form "error" and "ruin," his fiscal intention belies his goodwill. He cites that:

Whoever made his thank-offering to God could harvest his crops without fear of Ulu ... not just one yam ... as many as they wish according to the benefits, they received this year from God. And not only yams, any crop whatsoever or livestock or money (p. 216).

Ambivalently, Ezeulu's revenge on his own people was a catalyzer for the colonizers to use the gap as an opportunity to strengthen his power and hegemony in Umuaro. For whatever has been harvested in the name of Ulu before the natives' conversion, supersedes very rapidly by "Christian harvest". An excerpt from the novel illustrates this fast change.

The Christian harvest which took place a few days after Obika's death saw more people than even Goodcountry could have dreamed [...] many an Umuaro man had sent his son with a yam or two to offer to the new religion and to bring back the promised immunity (p. 230).

What Ezeulu wanted most was a desire for recognition or thymos, but strictly speaking, all things considered, he did not want such a catastrophic fate for his people. Thus, he loses his senses and goes mad. The akrastic person puts himself in a situation that his deeds receive no social support. Ezeulu's final akrasia brings up what Ngugi Wa Thiong'o calls "cultural bomb," meaning "to annihilate a people's belief in their names, in their languages, in their environment, in their heritage of struggle, in their unity, in their capacities and ultimately in themselves" (1994, p. 3). The desire for self-benefits leaves both Ezeulu and his indigenous rivals the victims of the colonial domination. Emmanuel Obiechina (1975) contends that as the "traditional authority" and judicial rights have been replaced by the "colonial authority," accordingly, "with the imposition of higher authority over Ulu, the minor gods see the situation as an opportunity to shake off an irksome hegemony" (p. 235). Peculiarly enough, in such as turmoil situation, Nwaka finds the opportunity to threaten Ezeulu's influence. Nonetheless, he is unaware that the colonial domination is putting an end to the hegemony of all the local gods, and their priests. Eventually, by looking into Ezeulu's bearings towards the white colonizers, in consonance with Edward Said's words, it can be deduced that "the influence of ideas, of institutions, and of other persons work not through domination but by ... consent" (Said, 2003, p. 7). Ironically, Ezeulu, with a view to refiguring his dignity and "self-esteem" (Fukuyama, p. 17) and also elevating his religious status to the same position of Ulu, fundamentally resulted in prompting the indigenous' break with "headstrong and ambitious priest" (Achebe, 1974, p. 230). He and people of his ilk allowed the colonists to establish their position firmly, such a miscalculation and akratic action intensified the pace of abandoning the local deities whose existence would guarantee their chief priests' power and Igbo culture at large.

\section{Conclusion}

In this article, Chinua Achebe's Arrow of God has been analyzed in relation to three parts of soul. Consistent with Francis Fukuyama's study of thymos, it is shown that both Ezeulu and the colonizers are striving to experience recognition in their interactions with the others. More particularly, it has been revealed that Ezeulu's desire to preserve his dignity with the aim of fastening the slackened bond between Ulu, the symbol of Igbo culture, and his people took several false steps. Likewise, his willingness to take revenge on his people and to teach them a lesson for their disrespect compelled him to hinge on the white colonizers' influence and neglect the natives' thymos. As a result, what is more obvious, Ezeulu mostly relied on his thymos than his noos, which led him to akrasia. To put it differently, his ambivalent and sadistic personality with intractable hubris impelled him to miscalculate the current events. Even though he could simply overlook his obstinacy or conceits, he allowed his noos to be subjugated to his thymos. Consequently, Ezeulu's akrasia resulted in his desire to preserve his dignity and holiness via Ulu, and to teach a lesson to the villagers again with the excuse of Ulu's will. Not only did this bring about his marginalization, but it also facilitated the colonizers' domination and recognition.

\section{References}

Allen, A. (1993). The Fragments of Mimnermus: Text and Commentary (pp. 59-64). Stuttgart: Franz Steiner Verlag Stuttgart.

Aristotle. (330 BC). The Politics (trans. Thomas A. Sinclair and Trevor Saunders, 1981). Harmondsworth, Middlesex: Penguin.

Ashcroft, B., Gareth, G., \& Helen, T. (2007). Post-colonial Studies the Key Concepts (2nd ed.). Abingdon: 
Routledge.

Bhabha, H. K. (1994). The Location of Culture. London: Routledge.

Butcher, S. H. (ed.) (1907). The Poetics of Aristotle. Macmillan.

Carroll, D., \& Chinua, A. (1990). Novelist, Poet, Critic. London: Palgrave Macmillan. https://doi.org/10.1057/9780230375215

Chambers, H. K. (2009). Sociolinguistic Theory. Oxford: Wiley-Blackwell.

Chinua, A. (1974). Arrow of God. New York: Anchor Books.

Darcus, S. M. (1977). -phrōn Epithets of Thumos (pp. 178-182). Glotta.

Destrée, P. (2007). Aristotle on the Causes of Akrasia. In K. A. Algra, F. A. J. de Haas, J. Mansfeld \& D. T. Runia (Eds.), Philosophia Antiqua A Series of Studies on Ancient Philosophy (pp. 139-165). Akrasia in Greek Philosophy, Brill. https://doi.org/10.1163/ej.9789004156708.i-308.39

Ferrari, G. R. F. (1992). Platonic love. In K. Richard (Ed.), The Cambridge Companion to Plato (pp. 248-278). Cambridge University Press. https://doi.org/10.1017/CCOL0521430186.008

Fukuyama, F. (2006). The End of the History and the Last Man. Simon Schuster.

Gourinat, J.-B. (2007). Akrasia and Enkrateia in Ancient Stoicism: minor vice and minor virtue (pp. 215-247)? Akrasia in Greek philosophy. Brill. https://doi.org/10.1163/ej.9789004156708.i-308.55

Henry, D. (2002). Aristotle on Pleasure and the Worst form of Akrasia. Ethical Theory and Moral Practice, 5(3), 255-270. https://doi.org/10.1023/A:1019843626299

Holton, R. (1999). Intention and weakness of will. The Journal of Philosophy, 96(5), 241-262. https://doi.org/10.2307/2564667

Hughes, G. J. (2013). The Routledge Guidebook to Aristotle's Nicomachean Ethics. Routledge. https://doi.org/10.4324/9780203082782

Jowett, B. (1998). The republic by Plato. The Pennsylvania State University.

Kalu, A. C. (1994). The Priest/Artist tradition in Achebe's Arrow of God. Africa Today, 41(2), 51-62.

Koziak, B. (1999). Homeric thumos: The early history of gender, emotion, and politics. The Journal of Politics, 61(4), 1068-1091. https://doi.org/10.2307/2647554

Le Bon, G. (2002). The Crowd: A study of the Popular Mind. Dover Publication.

Lear, J. (2009). The Socratic method and psychoanalysis. In A.-R. Sara \& R. Kamtekar (Eds.), A companion to Socrates (Vol. 126, pp. 442-445). https://doi.org/10.1111/b.9781405108638.2005.00030.x

Lewis, M. W. (1974). Ezeulu and His God. Black World, 24, 71-87.

Machila, B. N. (1981). Ambiguity in Achebe's Arrow of God. Kunapipi, 3(1), 14.

Maslow, A. H. (1970). Motivation and Personality. New York: Harper \& Row.

McConnell, T. (1975). Is Aristotle's Account of Incontinence Inconsistent? Canadian Journal of Philosophy, 4(4), 635-665. https://doi.org/10.1080/00455091.1975.10716082

Melamu, M. J. (1971). The Quest for Power in Achebe's Arrow of God. English Studies in Africa, 14(2), 225-240. https://doi.org/10.1080/00138397108690665

Mordaunt, O. G., Carillo, J., \& McGuire, M. (2021). Aspects of Gender and Socialization as Expressed Through Language. International Journal of Arts, Humanities \& Social Science, 2(7), 155-159.

Nwoga, D. I. (1981). The Igbo World of Achebe's 'Arrow of God'. Research in African Literatures, 12(1), $14-42$.

Obiechina, E. (1975). Culture, Tradition and Society in the West African Novel. Cambridge: Cambridge UP.

Osakwe, C. (2010). Literacy and Social Status in Achebe's Arrow of God and Soyinka's Isara. Journal of the African Literature Association, 5(1), 130-143. https://doi.org/10.1080/21674736.2010.11690150

Pennycook, A. (1998). English and the Discourses of Colonialism. London: Psychology Press.

Purviance, S. M. (2008). Thumos and the Daring Soul: Craving Honor and Justice. Journal of Ancient Philosophy, 2(2), 1-16. https://doi.org/10.11606/issn.1981-9471.v2i2p1-16 
Rorty, A. (1970). Plato and Aristotle on Belief, Habit, and 'Akrasia'. American Philosophical Quarterlyly, 7(1), $50-61$.

Said, E. W. (1994). Culture and Imperialism. New York: Vintage.

Said, E. W. (2003). Orientalism: Western Conceptions of the Orient. London: Penguin UK.

Scafe, S. (2002). Wherever Something Stands, Something Else Will Stand Beside It: Ambivalence in Achebe's Things Fall Apart and Arrow of God. Changing English, 9(2), 119-131. https://doi.org/10.1080/1358684022000006230

Sullivan, S. D. (1988). Noos and vision: Five Passages in the Greek Lyric Poets. Symbolae Osloenses, 63(1), 7-17. https://doi.org/10.1080/00397678808590811

Sullivan, S. D., \& Richard, D. S. (1990). An analysis of the Psychic Term vóo $̧$ in Pindar and Bacchylides. Glotta, 68(3/4), 179-202.

Wa Thiong'o, N. (1994). Decolonising the Mind: The Politics of Language in African Literature. Zimbabwe Publishing House.

\section{Notes}

Note 1 . The novel begins with a conflict between two neighborhood villages of Umuaro and Okperi over a plot of land. The conflict is triggered by a man known as Nwaka, who challenges Ezeulu and his god Ulu as well. Ezeulu, the chief priest of the god of Ulu, preaches against the war. Thereby, when the British colonial administrators steps in and distinguishes the flames of war, he gives verdicts against his people and in favor of the Okperi. Such an incident puts his reputations at risk and makes him the target of the critics in Umuaro. Being angry with disrespectful acts of his people, Ezeulu tries to take revenge of his people by postponing the harvesting date of yams. His plan does not move according to his calculations for starvation sweeps through Umuaro. Such famine results in the death of Ezeulu's favorite son and his own insanity. Eventually, this procedure and misjudgments accelerate the domination of the white man.

Note 2. A fictitious compound of six Igbo villages in eastern Nigeria: Umuachala, Umunneora, Umuaga, Umuezeani, Umuogwugwu and Umuisiuzo.

Note 3. On Gustave Le Bon's account, prestige is a kind of "great power" or "domination" that through "affirmation, repetition, and contagion" is given to conceptions and ideas (2002, p. 81).

Note 4. Also spelled thumos, in this article both spellings are used.

Note 5. vóoc in Greek and is also spelled nous.

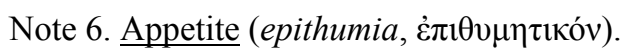

Note 7. Socrates, in the Republic, puts forward that there is a connection between "anger and "self-esteem". He suggests that "the nobler a man is ... the more angry he will become when he has been dealt with unjustly" (Fukuyama, 2006, p. 165). More pointedly, Abraham Maslow classifies "esteem needs" into two categories: first, esteem for oneself including: "the desire for strength, for achievement, for adequacy, for mastery and competence, for confidence in the face of the world, and for independence and freedom"; and second, the desire to be respected and valued by other people or the society like the "the desire for reputation or prestige, ... status, fame and glory, dominance, recognition, attention, importance, dignity, or appreciation" (1970, p. 45).

Note 8 . The Phaedrus ('fi:dres) is a book written by Plato based on a dialogue between $\underline{\text { Socrates, }}$ and Phaedrus, a mid-5th century BC aristocrat.

Note 9. In Ethics, Aristotle refers to "virtue" or "excellence" (arete) as a tendency towards doing something well. Aristotle distinguishes two types of virtue, intellectual virtue that engages in reasoning like good planning, and moral or ethical virtue that pertains to thymos like courage and generosity (Hughes, 2013, p. 21).

Note 10. Traditional Igbo religion includes belief in a Creator god, an earth goddess and numerous other deities and spirit, as well as ancestors who protect those who are living. Many Igbo are now Christians but some practice a creolist version of Christianity intermingled with indigenous practices. Prior to the colonial invasion, members of villages shared a common market and a meeting place and tutelary deity. And ancestral cults that supported a tradition of descent from a common ancestor or group of ancestors.

Note 11. See also Archibald Allen's The Fragments of Mimnermus: Text and Commentary (1993).

Note 12. Much has been written about sociolinguistic theory, particularly with regard to language and gender. 
Males "must be masculine by doing, talking, and being 'men"” (Mordaunt et al., 2021, p. 155). Also, age-graded changes recur at particular ages in successive generations (Chambers, 2009, p. 200). Language, sociologically, is generally connected to power. But hypothetically and significantly, language attitudes and forms of expression, such as those of Ezeulu, can be markers of both and power. In general, and "in all cultures older people tend to be less flexible and less tolerant than younger people" (p. 162) in terms of how they address others.

Note 13. Ezeulu is no doubt a tragic character in terms of is conflict and what happens throughout this story. There is tragic flaw in his character: his isolation, his age, his poor eyesight, his power struggle with his people, the colonizers, his imprisonment, and his defiance of is god Ulu. Obviously to the reader, Ezeulu is unwillingly preparing his own doom.

\section{Copyrights}

Copyright for this article is retained by the author, with first publication rights granted to the journal.

This is an open-access article distributed under the terms and conditions of the Creative Commons Attribution license (http://creativecommons.org/licenses/by/4.0/). 